\title{
Textual notes
}

\section{Anne Bradstreet}

The Tenth Muse Lately Sprung up in America, or Several Poems, Compiled with Great Variety of Wit and Learning, Full of Delight (1650; Wing B4I67, on $E E B O$ ) is the copy-text for all poems that occurred in it, collated with their revised versions in Several Poems, Compiled with Great Variety of Wit and Learning, Full of Delight (Boston, I678; Wing B4I66, on EEBO). Several Poems (1678) is the copy-text for poems that occurred only in it. The two versions of 'An Elegy upon that Honourable and Renowned Knight, Sir Philip Sidney' (I650 and I678) are reproduced in full; these are not collated against each other.

\section{The Prologue}

Copy-text: The Tenth Muse (I650)

4] And: $1678=$ Or

6] verse: $1678=$ lines

20] speak afterwards more: $1678=$ in future times speak

4I] each and all: $1678=$ all and each

46] wholesome: $1678=$ thyme or

47] ore $=\mathrm{I} 678$ (I650: stuff)

\section{The Four Monarchies}

Copy-text: The Tenth Muse (1650)

2] did not strive: $1678=$ did not proudly strive

6] son $=1678$ (I650: sons) Cush: $1678=$ Chus 
29] Bell: $1678=$ Baal

52] $1678=$ By force and fraud did under tribute bring

54] Pharmus: $1678=$ Thermus

60] drown: $1678=$ drowned

67] Philistines' = I678 (I650: Philistrius')

70] for what: $1678=$ for the crime

74] the $=\mathrm{I} 678$ ( 1650 : his)

82] Ninus of her amorous: $1678=$ Ninus amorous of her

9I] $\mathrm{r} 678=$ That underserved, they blurred her name and fame

92] As: $1678=\mathrm{By}$

97] were: $\mathrm{I} 678=$ was

I05] Most: $1678=$ Some

III] But: $1678=$ And

II5] beyond: $1678=$ above

I2 I] On Shinar ... by the Euphratian: $1678=$ In Shinar ... on the

Euphratian

I24] Staurobates, his country = I678 (I650: Great King Staurobates, for)

I26] man: $1678=$ may

I29] marvellous: $1678=$ wonderful

I3I] Indus: $1678=$ Judas [identified as an error in I678 errata leaf] 3267-68] omitted in 1678

3272] At Actium slain, his navy: $1678=$ At Actium, where his navies

3272] Following this line, I678 adds: He seeing his honour lost, his

kingdom end, / Did by his sword his life soon after send.

3273] Then poisonous asps she sets unto: $1678=$ His brave virago asps

sets to

3297] that: $1678=$ the

3305] But yet: $1678=$ Yet shall

3306] that: $1678=$ the

33II] a: $1678=$ some

3320] Ne sutor ultra crepidam $=$ I678 (I650: Ne suter ultra crepidum)

3329] in best: $1678=$ in good

3332] into th'world: $1678=$ to the world

3338] made: $1678=\mathrm{kept}$

3342] walls: $1678=$ wall

335I] these: $1678=$ those

3360] For: $1678=$ Then

3366] Some feigning say to heav'n: $1678=$ Some feigning to the gods

3369] is next chosen: $1678=$ next chose they

3372] but ope: $1678=$ set ope

3375] habit: $1678=$ gestures

3377] Goddess: $1678=$ The nymph 
3380] some: $1678=\mathrm{a}$

3384] The: $\mathrm{I} 678=$ This. $\mathrm{did}=\mathrm{I} 678$ ( $1650: \mathrm{do}$ )

3387] conquer, others yield: $1678=$ conquer, the other yield

3388] for: $1678=$ in

3394] Leaves: $1678=$ Left

3402] year th'time: $1678=$ years time

3406] $1678=$ Who from his country for sedition fled

34I4] Much state and glory: $1678=$ Some state and splendour

3415] stranger: $1678=$ stronger [identified as an error in I678 errata leaf]

3417] sits upon: $1678=$ get into

3435] with speed: $1678=$ by force

3440-59] I678. 'An Apology' is not included in I650.

\section{A Dialogue between Old England and New}

Copy-text: The Tenth Muse (1650)

I4] weakened fainting: $1678=$ fainting weakened

26] wound's: $1678=$ wound

29] fraud and force: $1678=$ fraud or force

30] And by: $1678=$ Or by

46] $1678=$ Pray do you fear Spain's bragging armado?

48] do = I678 (I650: doth)

50] this: $1678=$ the

6I] and: $1678=$ nor

64] Lewis: $1678=$ Jews

67-68] omitted in 1678

70] In 1678, two lines are added after line 70: No crafty tyrant now

usurps the seat / Who nephews slew that so he might be great.

86] thy: $1678=$ our

93] And: $1678=$ Are

94] trodden = I678 ( $\mathrm{I} 650$ : is trod)

95] were $=\mathrm{I} 678$ ( 1650 : are)

I03] wast: $\mathrm{I} 678=$ wert

I04] I: $1678=$ was

I07] bloods: $1678=$ blood

II ] which I have: $1678=$ by great ones

I12] O, Edward's babes: I678 = Of Edward's youths

I 5] for thefts, and lies: I678 = and lies

I27-30] omitted in I678, and replaced with: I then believed not, now I

feel and see / The plague of stubborn incredulity.

I32] $1678=$ Some fined, from house and friends to exile went 
I34] $1678=$ Who saw their wrongs, and hath judged righteously

I43] yielding: $1678=$ yielded

I57] hands: $1678=$ hearts

I6I] says: $\mathrm{I} 678=$ said

I62] $\mathrm{I} 678=$ 'Tis said, my better part in parliament

I63] show: $1678=$ showed

I66] come: $\mathrm{I} 678=$ came

I90] cause: $1678=$ strife

193] the worst, the best may overthrow: $1678=$ but this may be my overthrow

I94-95] omitted in 1678

198] ravished: $1678=$ weeping

206-07] 1678: For my relief, do what there lies in thee, /And recompense that good I've done to thee.

210] I once: $\mathrm{I} 678=$ and I

2I2-I3] I678: Your griefs I pity, but soon hope to see / Out of your troubles, much good fruit to be

214] these: $1678=$ those

215] $1678=$ Though now beclouded all with tears and blood

222] which do: $1678=$ who did

226] them $=1678$ ( $1650:$ those)

23I] prelates: $1678=$ popelings

232] out: $1678=$ forth

234] such trash: $1678=$ such empty trash

238] show whose son thou art: $1678=$ with a loyal heart

239] nor country in thy heart: $1678=$ nor to the better part

24I] By force expel, destroy: $\mathrm{I} 678=$ As duty binds, expel

242-43] omitted in 1678

245] blessèd: $1678=$ hopeful

25I] will: $\mathrm{I} 678=$ shall

26I] for: $\mathrm{I} 678=\mathrm{oft}$

268] thy valour: $1678=$ and glory

273] Execute to th'full: $\mathrm{I} 678=$ And on her pour

294] parliament: $1678=$ rightest cause

\section{An Elegy upon that Honourable and Renowned Knight, Sir Philip Sidney [1650]}

Copy-text: The Tenth Muse (1650). See p. 76 for the 1678 version of this poem.

34] Fond $=1678$ (I650: Found) 
In Honour of Du Bartas, I64I

Copy-text: The Tenth Muse (1650)

I] Amongst: $1678=$ Among

I9] I fitly may compare: $1678=$ I may compare

33] And: $1678=$ But

55] in him thou didst: $1678=$ thou didst in him

56] Pepin, Martel: $1678=$ Martel, Pepin

58] in blood, in scars: $1678=$ in wars, in blood

64] all men to thee: $1678=$ to thee all men

$7 \mathrm{I}$ ) are: $1678=$ is

72] name $=1678$ ( $1650:$ names). or: $1678=$ and

In Honour of that High and Mighty Princess, Queen

Elizabeth, of Most Happy Memory

Copy-text: The Tenth Muse (1650)

Title] of Most Happy: 1678 = of Happy

I8] greatness: $1678=$ praises

24] eleven Olympiads $=1678$ ( $1650:$ nine Olympiads)

33] had not in force now been: $1678=$ in force now had not been

$38]$ once a year $=1678$ ( 1650 : twice a year)

43] so: $1678=$ more

48] for: $1678=$ there

56] Before her picture the proud Tyrone fell $=1678$ ( 1650 : And Tyrone bound, before her picture fell)

59] Such soldiers and such captains: $1678=$ Such captains and such soldiers

62] her: $1678=$ the

63 laden $=\mathrm{I} 678(\mathrm{I} 650=$ laded $)$

65] wit: $1678=$ tongue

69] placed: $1678=$ built

70] time: $1678=$ while

73] at: $1678=$ of

8I] Proud, profuse: $1678=$ Profuse, proud

I02] O: $\mathrm{I} 678=$ Yea

I09] must: $1678=$ shall 
David's Lamentation for Saul and Jonathan, 2 Samuel I:I9

Copy-text: The Tenth Muse (I650)

13] For there the mighty ones $=1678$ (I650: For the mighty ones)

20] Did Saul with bloodless sword: $1678=$ With bloodless sword did Saul

22] deaths: $1678=$ death

33] wert: $1678=$ wast

35] Distressed I am for thee: $\mathrm{I} 678=$ Distressed for thee $I$ am

36] surpassing $\operatorname{man}=1678$ ( 1650 : passing a man)

An Elegy upon that Honourable and Renowned Knight, Sir Philip Sidney (I678)

Copy-text: Several Poems (1678). See p. 59 for the 1650 version of this poem.

The Flesh and the Spirit

Copy-text: Several Poems (1678)

The Author to her Book

Copy-text: Several Poems (I678)

A Letter to her Husband, Absent upon Public Employment

Copy-text: Several Poems (I678)

Another ['As loving hind']

Copy-text: Several Poems (I678)

In Memory of my Dear Grandchild Elizabeth Bradstreet, who Deceased August I605, Being a Year and Half Old

Copy-text: Several Poems (I678) 


\section{Hester Pulter}

Pulter's poems occur only in University of Leeds, Brotherton Collection, MS Lt q 32, which is our copy-text. Some comparisons with Eardley's Lady Hester Pulter (2014) are noted.

\section{The Invitation into the Country, to my Dear Daughters}

Title: Dear Daughters M.P., P.P.: MS = D: D: M: P: P: P:

Title] Unhappy Hour. Eardley suggests 'Unhappy [Holmby]'.

4] Five: this word has been overwritten in the MS, and is difficult to decipher. Eardley transcribes as 'Fierce'. usurp: MS = usurps

5] planes: Eardley transcribes as 'fanes' (temples).

59] both: In the MS, 'doth' has been crossed out and 'both' inserted above.

67] posies: $\mathrm{MS}=$ poses

7I-72] The couplet has been inserted into the left-hand margin in Pulter's autograph hand, with its placement after line 70 indicated by an ' $x$ '. In the main text, line 70 leads directly into line 73 , without a stanza break, but the inserted couplet implies that there should be one between lines 72 and 73 .

95] Mimram: $\mathrm{MS}=$ Mimmer

I54] Hangs: $M S=$ Hang

I55] Napaeae: $M S$ = Napeas

I63] violets: $M S=$ vi-letts

\section{The Complaint of Thames, I647}

46] showing: $M S$ = shewing, and Pulter's meaning is not entirely clear.

Eardley suggests 'eschewing'.

5I] she'd ne'er: $M S$ = she would ne're

55] looked: $\mathrm{MS}=$ took

69] Horatius' valour: $\mathrm{MS}=$ Horatia's vallure

85] they'd: MS = they would

I03] despair: $M S=$ despairs

II5] breathe: $M S=$ breaths 
On those Two Unparalleled Friends, Sir George Lisle and Sir Charles Lucas

Title] The eighteenth-century annotating hand has added 'who were shot to death at Colchester'.

7] Areopagus: $\mathrm{MS}=$ Areopagie

I4] two: Eardley transcribes as 'too'

29] t'embrace: $M S=$ to embrace

43] hurrying: $M S$ = hurring. Eardley retains 'hurring' here (which means to snarl or growl).

53] they've: $M S=$ they have

84] In the MS 'triumph' is deleted and 'glory' inserted in its place.

Upon the Death of my Dear and Lovely Daughter, J.P.

28] splendency: $\mathrm{MS}=$ splendentie

4I] posies: $\mathrm{MS}=$ poses

43] The line to close this couplet, 'Like drops of blood upon unsoiled snow', is scored out.

44-52] A pointing finger device and the words 'videre retro 27 ' (i.e. look back 27') direct the reader to page 27 in the manuscript (fol. I6r), where lines $44-52$ of the poem are added into spare space (see Figures 2 and 3 ).

On the Same ['Tell me no more']

26] Muses': MS = Museses

On the Horrid Murder of that Incomparable Prince, King Charles the First

Title] Murder: MS $=$ Murther

2] unparalled: $M S$ = unparrild

On the Same ['Let none sigh more']

4] sovereign's: $\mathrm{MS}=$ sovereign

Io] unto: $M S=$ into

I5] unparalled: $\mathrm{MS}=$ unparrild 
'Dear God turn not away thy face'

This poem is untitled in the MS, as are most of Pulter's devotional poems.

The Circle ['Those that the hidden chemic art profess']

I] chemic: $\mathrm{MS}=$ Chimick

3] philtres: $\mathrm{MS}=$ filterys

\section{On the King's Most Excellent Majesty}

The poem seems initially to have been titled 'On the King' (in Pulter's hand, not that of the main scribe), with the alteration and addition made in a different hand.

5] bright Minerva's: These words are written above 'Pallas' sacred' in the MS, but it is unclear which is the preferred reading ('Pallas' sacred' is underlined but not scored out).

II] unparalled: $\mathrm{MS}$ = unparrild

To my Dear J.P., M.P., P.P., they Being at London, I at Broadfield

Title] Broadfield: $\mathrm{MS}=$ Bradfield

I] lonely: $\mathrm{MS}=$ lovly (apparently a scribal error)

\section{'Must I thus ever interdicted be?'}

This poem is untitled in the MS, as are most of Pulter's devotional poems.

\section{'Why must I thus forever be confined'}

This poem is untitled in the MS, as are most of Pulter's devotional poems.

55] ones': $M S$ = on's

94] I'd: MS = I wo'd 
To Sir William Davenant, upon the Unspeakable Loss of the Most Conspicuous and Chief Ornament of his Frontispiece

Title] William Davenant: $M S=\mathrm{W}^{\mathrm{m}}$. D.

9, 33] slight: $\mathrm{MS}=$ sleight

The Weeping Wish

Title] The poem is dated January I665, directly beneath the title. I2] Artemisia's: MS: Artimitius

\section{Emblem 20}

8] lay: $M S$ = say

I7] Artemesia's: $M S=$ Artimitius

48] In fine: $M S=$ Infine

50] So: $\mathrm{MS}=\mathrm{To}$

\section{Emblem 22}

I9] is pursued: These words are obscured in the MS due to damage. 22] broke: Eardley transcribes as 'breaks'.

\section{Katherine Philips}

The autograph 'Tutin' manuscript, National Library of Wales, MS 775B, is our copy-text for poems that occur in it. We have used Poems by the Incomparable Mrs. K.P. (I664; Wing P2032, on EEBO) for those that are not in Tutin; and we have used Poems by the Most Deservedly Admired Mrs Katherine Philips, the Matchless Orinda; to which is added Monsieur Corneille's Pompey \& Horace, Tragedies; With Several Other Translations Out of French (1667; Wing P2033, on EEBO) for poems that occur in neither of the earlier two copy-texts. Each of these copytexts is collated against the others. The exceptions to this policy are two poems that occur only in partial copy in the Tutin manuscript, 
'To the Right Honourable Alice, Countess of Carbery, on her Enriching Wales with her Presence' and 'Orinda upon Little Hector Philips'. The copy-texts for these poems are the more complete copies in Poems (I664) and Poems (I667) respectively, and are collated against Tutin.

To my Dearest Antenor, on his Parting

Copy-text: Tutin

I3] its own: $1664=$ in its

\section{A Retired Friendship, to Ardelia}

Copy-text: Tutin

Title] 23rd August I65I: I664; I667 [no date]

27] neighbour: $1664 ; \mathrm{I} 667=$ neighbouring

27] streams: $\mathrm{I} 664=$ springs

30] Whoever would not: $1664 ; \mathrm{I} 667=$ Who would not ever

\section{Friendship's Mysteries, to my Dearest Lucasia}

Copy-text: Tutin

Title] Mysteries: I664; I667 = Mystery

II] their: $1664 ; \mathrm{I} 667=$ the

I7] Than Thrones more great and innocent: $\mathrm{I} 664=$ Than greatest thrones more innocent

2I] tedious: $\mathrm{I} 664=$ odious

\section{Content, to my Dearest Lucasia}

Copy-text: Tutin

9] or: $\mathrm{I} 664 ; \mathrm{I} 667=$ and

28] is: $\mathrm{I} 667=$ he's

37] But: $\mathrm{I} 664 ; \mathrm{I} 667=$ But yet

46] wish: $1664 ; \mathrm{I} 667=$ wish for

48] made: $\mathrm{I} 664 ; \mathrm{I} 667=$ born

53] so: $\mathrm{r} 664=$ still 


\section{Textual notes}

54] Their very griefs imparted lose that name: $\mathrm{I} 664 ; \mathrm{I} 667=$ Their griefs, when once imparted, lose their name

6I] we who have: $\mathrm{I} 664=$ we have

Friendship in Emblem, or the Seal, to my Dearest Lucasia

Copy-text: Tutin

Stanza 5 ('From smoke ... consumed') is inserted in the manuscript after the other verses have been transcribed.

28] the other: $\mathrm{I} 664=$ each other; $\mathrm{I} 667=$ this other

44] law: $1664 ; \mathrm{r} 667=$ unto

46] and numbers: $\mathrm{I} 664 ; \mathrm{I} 667=$ in number

54] even: $1664 ; 1667=$ ever

58] mine: $\mathrm{I} 664 ; \mathrm{I} 667=\mathrm{mind}$

$6 \mathrm{I}$ ] is: $\mathrm{I} 664 ; \mathrm{I} 667=$ are

\section{The World}

Copy-text: Tutin

2] too early: $\mathrm{I} 667 ; \mathrm{I} 664$ = untimely

8] mischief: $\mathrm{I} 664 ; \mathrm{I} 667=$ mischiefs

I8] And, so far from: $\mathrm{I} 667=$ So far even from

20] an: $\mathrm{r} 664 ; \mathrm{I} 667=$ one

23] are: $\mathrm{I} 667=$ is

45] But: $\mathrm{I} 664 ; \mathrm{I} 667=$ Our

5I] Errors: $\mathrm{I} 664 ; \mathrm{I} 667=$ Error

54] we can't: $\mathrm{I} 667=$ cannot

55] men who plod on: $\mathrm{I} 664 ; \mathrm{I} 667=$ men now, who plod

84] or sting: $\mathrm{I} 664 ; \mathrm{I} 667=$ their sting

86] find: overwrites 'seek'. $1664 ; \mathrm{I} 667=$ find

93] grope and play and cry: $\mathrm{I} 664=$ grapple, play and cry; $\mathrm{I} 667=$ grovel, play and cry

\section{The Soul}

Copy-text: Tutin

2] roam: $1664=$ come

I2] our own: I664; I667 = our 
33] made body: $\mathrm{I} 664=$ made a body; $\mathrm{I} 667=$ body made

46] her clotty: $\mathrm{I} 664=$ a clotty; $\mathrm{I} 667=$ a sordid

56] immortality: $\mathrm{I} 664=$ mortality

65] shortens: $1664 ; \mathrm{I} 667=$ shorten

78] keep: $\mathrm{I} 664 ; \mathrm{I} 667=$ keeps

79] And those who yield to what: $\mathrm{I} 667=$ Who yield to all that does

\section{Invitation to the Country}

Copy-text: Tutin

I3] laurels pressed their: I664; I667 = laurel pressed the

2I] fate: $\mathrm{I} 664=\mathrm{it}$

34] sting that: $\mathrm{I} 664=$ thing that

36] wholly: $\mathrm{I} 664 ; \mathrm{I} 667=$ only

42] When: $1664 ;$ i667: Where

49] most: $\mathrm{I} 664 ; \mathrm{I} 667=$ world

50] will: $\mathrm{r} 664=\mathrm{can}$

On the 3rd September I65I

Copy-text: Tutin

5] As if: $1664 ; 1667=$ And as

I8] wait upon: I667; I664 = else attend

25] Thus captive: $1667 ; \mathrm{I} 664=$ And captiv'd

3I] thus: $\mathrm{I} 664 ; \mathrm{I} 667=$ so

32] the: $1664 ; 1667=a$

2 Corinthians 5:I9, God was in Christ reconciling the world to himself, 8th April I653

Copy-text: Tutin

Title] 8th April I653: I667 = [no date]

5] Christ: expanded from ' $\mathrm{C}$ ' ( $(\mathrm{I} 664 ; \mathrm{I} 667=$ Christ $)$

9] was in so much misery: $\mathrm{I} 664 ; \mathrm{I} 667=$ in such misery was

Iо] make: $\mathrm{I} 664=$ made

II] lump: $1664 ; \mathrm{r} 667=$ load

I9-26] omitted in 1667

27] hath made he therefore: $\mathrm{I} 667=$ himself hath made he 
28] it's: $\mathrm{I} 664 ; \mathrm{I} 667=$ 'tis

32] 'Tis equal: $\mathrm{I} 667=$ Shews more his

34] would: $1664 ; \mathrm{I} 667=$ could

47] men: $1664 ; 1667=\sin$

Upon the Double Murder of King Charles I, in Answer to a Libellous Copy of Rhymes Made by Vavasor Powell

Copy-text: 1664

3] dangers: $1667=$ danger

5] here's a fair: $\mathbf{I} 667=$ this is a

27-28] omitted in 1667

On the Numerous Access of the English to Wait upon the King in Flanders

Copy-text: 1664

4] $\mathbf{r} 667$ = As Pompey's camp, where'er it moved, was Rome

Io] Will itself: $1667=$ Itself will

22] so long lost: $\mathrm{I} 667=$ prodigious. did still: $\mathrm{I} 667=$ still $\mathrm{did}$

Arion on a Dolphin, to his Majesty at his Passage into England

Copy-text: 1664

Title] I667. I664 = Arion to a Dolphin, on his Majesty's Passage into

England

2I] Had plots for: $\mathrm{I} 667=$ Plots against

7I] Disgusted: $\mathrm{I} 667=$ Discovered

On the Fair Weather Just at Coronation

Copy-text: 1664

Title] $\mathrm{I} 667=$ On the Fair Weather Just at the Coronation, it Having Rained Immediately Before and After

8] a more bright: $\mathrm{I} 667=$ in a bright

I2] I667. The line is missing in I664, the lacuna indicated by a line of asterisks. 


\section{On the Death of the Queen of Bohemia}

Copy-text: 1664

3] hath so far: $1667=$ so far hath

2I] suit begged to have: $\mathrm{I} 667=$ tribute begged t'have

24] bravely: $\mathrm{I} 667$ = greatly

26] the: $1667=$ his

39] devotion $=\mathrm{I} 667$ ( 1664 : directions)

To the Right Honourable Alice, Countess of Carbery, on her Enriching Wales with her Presence

Copy-text: I664 (Tutin contains lines I-20 only, the leaf containing the third stanza having been excised.)

Title] on her Enriching Wales with her Presence: $\mathbf{1 6 6 7}=$ at her Coming into Wales

In Tutin, the poem begins with an address, on its own line, 'Madam'.

4] so: $1667=$ let

5] our $=\mathrm{I} 667$ (Tutin; I664 = your). deemed: Tutin $=$ doomed

6] in: Tutin $=$ to

I2] do't: Tutin = pay't

I3] Tutin: It is perfection's misery, that art and wit

23] splendour: $\mathrm{I} 667=$ splendours

To Antenor, on a Paper of Mine which J. Jones Threatens to Publish to Prejudice him

Copy-text: I664. Hageman believes that the poem was originally in Tutin, but has been excised ('Treacherous Accidents', p. 9I).

Title] J. Jones: $\mathrm{I} 667=\mathrm{J}$. J.

I] his: $\mathrm{I} 667=$ thy

I4] verse: $\mathrm{I} 664=$ Virge; $\mathrm{I} 667=$ verse

\section{A Country Life}

Copy-text: 1664

IO-I2] $1667=$ Here taught the multitude; $/$ The brave they here with honour fired, / And civilised the rude.

33] Such as: $1667=$ Them that 
4I] roar $=\mathrm{I} 667$ (I664: wear)

59] There: $\mathrm{I} 667=$ Then

6r] knew: $\mathrm{r} 667=$ know

85] integrity: $1667=$ and humble seat

86] noise: $\mathrm{I} 667=$ strife

87-88] $\mathrm{I} 667=\mathrm{I}$ am not forced to make retreat $/$ But choose to spend my life.

Upon Mr Abraham Cowley's Retirement. Ode.

Copy-text: 1664

40] thee: $1667=$ these

44] will be unconcerned: $\mathrm{I} 667=$ must be unconcerned

48] But of: $\mathrm{r} 667=$ But that of

57] innocence: $\mathrm{I} 667=$ innocent

Epitaph on her Son H.P. at St Sith's Church, where her Body also Lies Interred

Copy-text: 1667

To my Antenor, March I6 I66I/2

Copy-text: 1667

\section{Orinda upon Little Hector Philips}

Copy-text: I667 (The first two stanzas of the poem, only, are in the Tutin MS.)

Title] Tutin $=$ On the Death of my First and Dearest Child, Hector Philips, Born the 23rd of April and Died the 2nd of May I655. Set by Mr Lawes.

I] in = Tutin (I667: of)

6] touch $=$ Tutin (I667: pluck)

8] So = Tutin (I667: For) 


\section{Margaret Cavendish}

Our first copy-text is Philosophical Fancies (I653; Wing N865) for poems that occurred in it. Poems that occurred in Poems and Fancies (I653) and Poems and Fancies (1664) are taken from Poems, and Fancies, Written by the Thrice Noble, Illustrious, and Excellent Princess the Lady Marchioness of Newcastle. The Second Impression, Much Altered and Corrected (I664). British Library shelfmark I664 G.I9054. These poems are collated with Poems and Fancies (1653; Wing N869, on EEBO, and in the Scolar Press facsimile (Menston, Yorkshire: Scholar Press, I972)).

Of Sense and Reason Exercised in their Different Shapes

Copy-text: Philosophical Fancies (1653)

A Dialogue between the Body and the Mind

Copy-text: Philosophical Fancies (1653)

An Elegy

Copy-text: Philosophical Fancies (1653)

\section{The Poetress's Hasty Resolution}

Copy-text: Poems and Fancies (I664)

3] And thinking them so good, thought more to make: $1653=$ Thinking them so good, I thought more to write

4] take: $1653=$ like

5] thought, lived I many a year: $1653=$ I thought, if I lived long

6] thereon to rear: $1653=$ to build thereon

9] he: $1653=$ she

II] and do: 1653 = said she

I3] already hath great store: $1653=$ hath already such a weight

I4] wherefore do write no more: $1653=$ as it is over fraught

I5] But: 1653 = Then

I6] into th'fire: $1653=$ in the fire 
I8] he: $1653=$ she

2I] repent with grief: $\mathrm{I} 653=$ with grief repent

\section{A World Made by Atoms}

Copy-text: Poems and Fancies (I664)

2] For being subtle, every shape they take: $1653=$ As being subtle, and of every shape

3] they: 1653 = fit

4] Of forms, that: $1653=$ Such forms as

5] or: $\mathrm{I} 653=$ and

9] as they: $1653=$ not fit

I2] And there remaining close and fast will knit: $1653=$ They there remain, lie close, and fast will stick

I3] which not fit: $1653=$ that unfit

I5] Thus by their forms, and motions they will be: $1653=$ Thus by their several motions, and their forms

I6] Like workmen, which amongst themselves agree: $1653=$ As several work-men serve each other's turns

I7] so: $1653=$ thus

I8] predestinate, may work by fate: $\mathrm{I} 653=$ predestinated to work my fate

\section{Of the Subtlety of Motion}

Copy-text: Poems and Fancies (I664)

3] We should of unknown things dispute no more: $1653=$ We should adore God more, and not dispute

4] How they be done, but the great God adore: $1653=$ How they are done, but that great God can do't

7] which God in us did raise: 1653 = which nature's God did give

8] To worship him, and in his works to praise: $\mathrm{I} 653=$ Us to adore him, and his wonders with

II] We: $1653=$ But

I2] But proud: $1653=$ Proudly

\section{Of Vacuum}

Copy-text: Poems and Fancies (I664)

4] should: $1653=$ might 
5] is like to a: $1653=$ like is to the

6] doth go: $1653=$ goeth

6] comes: $1653=$ takes

7] since: $1653=$ though

8] they: $1653=$ first

9] filled up: 1653 = first full

Io] Room, for succeeding atoms place to take: $1653=$ Room for succession, their places for to take

II] Wherefore if: $1653=$ But as those

I2] They needs must empty places have to go: ${ }^{6} 653=$ Yet still in empty places must they go

\section{Of Stars}

Copy-text: Poems and Fancies (I664)

I] that in th': $1653=$ in the

2] ne'er did: $1653=$ did ne'er

7] who knows but those: $1653=$ who doth know, but

Io] As our imaginations thither fly: $1653=$ As well as can imaginations high

II] we might as little: I653 = as little may we

I2] up do: $1653=$ do up

\section{A World in an Earring}

Copy-text: Poems and Fancies (I664)

I] earring: $1653=$ earring round

2] which: $1653=$ and

4] learned: $\mathrm{r} 653=$ some wise

8] we call the north and southern-pole: $1653=$ which we do call the pole

9] winters: $1653=$ winter

II] lightning: $\mathrm{I} 653=$ lightnings

I3] Fish there may swim in seas, which ebb and flow: $1653=$ There seas may ebb, and flow, where fishes swim

I4] wherein do spices grow: $1653=$ where spices grow therein

I7] Earthquakes may be: $1653=$ There earthquakes be

I9] Meadows may: $1653=$ There meadows

2I] fine: $\mathrm{I} 653=$ fresh 
23] There may be night and day, and heat and cold: $1653=$ There night, and day, and heat, and cold, and so

24] As also life and death, and young and old: $1653=$ May life, and death, and young, and old, still grow

25] And: $\mathrm{I} 653=$ Thus

26] infection: $1653=$ infections

27] Great cities there may be, and houses built: $1653=$ There cities be, and stately houses built

28] Whose: $1653=$ Their

29] Churches may they've, wherein priests teach and sing: $1653=$ There churches be, and priests to teach therein

30] steeples: $1653=$ steeple

3I] up run: $1653=$ run

33] Markets may be, where things are: $1653=$ There markets be, and things both

34] Though th'ear not knows the price their markets hold: $1653=$ Know not the price, nor how the markets hold

35] may ... may: $1653=$ do ... do

36] And battles may be fought, and many slain: $1653=$ And battles fought, where many may be slain

38] Whence they no: $1653=$ And yet not

39] this: $1653=$ the

43] Rivals may duels: $1653=$ There rivals duels

44] And: $1653=$ There

48] are into Elysium gone: $\mathrm{I} 653=$ they into Elysium run

The Purchase of Poets, or A Dialogue Betwixt the Poets, and Fame and Homer's Marriage

Copy-text: Poems and Fancies (I664)

2] upon which Fame: $1653=$ where Fame thereon

4] Of which all those that drink: $1653=$ Which those that drink thereof

5] they're all: $1653=$ Poets all are

7] might make: $1653=$ should get

8] They all agreed they would some counsel take: $1653=$ They did agree in council all to sit

9] owner: $1653=$ honour

I2] That they might: $1653=$ And for to

I3] a: $1653=$ the

I4] Some nimbler feet had $=$ I653 (I664: Some had nimbler feet had) 
I4] a: $1653=$ their

22] did: $1653=$ doth

27] Then: $\mathrm{I} 653=$ Straight

28] strove: 1653 = strong

30] For him was Greece and Troy bound; then came in: $1653=$ Brought Greece, and Troy for to be bound for him

3I] Virgil who brought: 1653 = Virgil brought

32] did come: 1653 = came soon

33] For Juv'nal and Catullus: $1653=$ Juvenal, Catullus

35] Tibullus, Venus and her son did bring: $1653=$ And for Tibullus, Venus, and her son

36] For him, 'cause wanton verses he did sing: $1653=$ Would needs be bound, 'cause wanton verse he sung

38] For Ovid, sealing's bond with several things: $\mathrm{I} 653=$ Ovid, who seals the bond with several things

39] th'senate: $1653=$ senate

40] his: $1653=$ their

4I] Who mustered all i'th'Parthian fields, their hand: $1653=$ Mustering them all in the Emathian Fields

42] And seal did freely set to Lucan's band: $1653=$ To Fame's bond to set their hands, and seals

44] and would fair Fame: 1653 = fair Fame for to

47] at the: $1653=$ all at

48] But: $1653=$ Which

50] Who did dispute, which should Fame's husband be: $1653=$ Where Fame disputed long, which should her husband be

5I] thought it meet: $1653=$ first did speak

52] To speak, whose: $1653=$ And said, his

53] Ladies, said he, are for varieties: 1653 = Variety, said he, doth ladies please

54] And: $1653=$ They

62] whose high praise he in his verse: $1653=$ in his verse his praises high

63] Venus: 1653 = fair Venus

64] Let him your husband be, none other take: $1653=$ And for your husband no other may you take

65] Then wise Ulysses in a rhet'ric style: $1653=$ Wise Ulysses in an orator's style

66] his: $1653=$ whose

67] He bowed his head, and thus: $1653=$ Bowing his head down low

7I] Homer his lofty strain to heav'n flies high: $1653=$ Homer's lofty verse doth reach the heavens high

74] He's: $1653=\mathrm{As}$ 
75] Then walks he down to the: $1653=$ So walks he down into

77] about: $1653=$ above

80] Elysian: $1653=$ Elysium

8I] Tells you how lovers there: $\mathbf{I} 653=$ There tells you, how lovers

82] how: $1653=$ that

83] make by: $\mathrm{I} 653=$ make

84] So do the souls: $1653=$ So souls do

86] Th'Olympic: $\mathrm{I} 653=$ At the Olympic

87] how they run, leap, wrestle, swim and ride $=1653$ : As wrestling, running, leaping, swimming, ride

88] With: $1653=$ And

89] ever did before him: $\mathrm{I} 653$ = before him, did ever

90] The gods in heav'n, and devils' names in hell: $1653=$ The names of all the gods, and devils in hell

93] elder much than: $1653=$ which were before all

96] as: $1653=$ else

97] Else: $\mathrm{I} 653=\mathrm{It}$

I02] arts brought in: $1653=$ brought arts in

I03] now made: $1653=$ made

I04] Which quenched, you'd: $1653=$ Quenched out, you

I05] heats men's spirits, and: $1653=$ It heats the spirits of men

III] you should thieves, that pick the purse: $1653=$ thieves, that pick the purse, you should

II2] when: $1653=$ since

II3] servant: $\mathrm{I} 653=$ servants

II4] Each from him steals, and so: $1653=$ Thieves steal, and with the same

II5] 'twill be a heinous fact: $1653=$ the world will never care

II6] if you from right detract: $1653=$ unless you right prefer

II9] your: $1653=$ thy

I20] your: $1653=$ thy

I2I] Then at your word, I'll: I653 = I, at your word, will

I22] prove: $\mathrm{I} 653=$ proves

I24] And they were: $1653=$ Then were they

I28] but: $\mathrm{I} 653=$ were

I29] In measure and in time they danced about: $1653=$ Then did they dance with measure, and in time

I30] the Muses nine took out: $1653=$ took out the Muses nine

13I] did run their nimble feet: $1653=$ their feet did run

I32] sung most sweet: $1653=$ sung

I33] At last the: $1653=$ The

I34] And there did Homer get: $1653=$ There Homer got 


\section{A Dialogue betwixt Man and Nature}

Copy-text: Poems and Fancies (I664)

I] 'Tis most: $\mathrm{I} 653=$ 'Tis

4] Is the greatest: $1653=$ Is a great

5] for nought but pains: $1653=$ great pains

6] only to be: $1653=$ to be

7] reason, and yet not to know: $1653=$ sense, and reason too

8] What we are made for, or what we must do: $1653=$ Yet know not what we're made to do

9] to heaven: $1653=$ heaven up

Io] change into new forms: $1653=$ into new forms change

II] to the prime matter: $\mathrm{I} 653=$ to matter prime to

I2] Thence take new forms, and so always: $1653=$ From thence to take new forms, and so

I4] which do torment his: $1653=$ to torment the

22] they: $1653=$ will

23] Which cruelly they: $1653=$ Most cruelly do

24] And form it as they please, then build: $1653=$ And forms it as he please, then builds

25] to stand, was graced: $1653=$ was made to stand

26] by none to be defaced: $1653=$ not to be cut by Man

28] no: $1653=$ not

29] passions: $\mathrm{I} 653=$ passion

3I] before the time, which I: $\mathrm{I} 653=\mathrm{I}$ gave, before the time

32] Ordained for them, 's to me an injury: $\mathrm{I} 653=\mathrm{I}$ did ordain, the injury is mine

34] And: $1653=$ For

36] good: $\mathrm{I} 653=$ either good

37] beasts have sense, feel pain: 1653 = beast hath sense, feels pain

39] Beasts have: $1653=$ Beast hath

42] and: $1653=$ with

43] Desire doth whip and makes him run amain: $1653=$ Desire whips him forward, makes him run

46] though: $1653=$ yet

49] and drink, and all be well: $\mathrm{I} 653$ = or drink, or lie stone-still

50] neither for heav'n, nor hell: 1653 = either for heaven, or hell

53] He has this knowledge, that: $1653=$ And knowledge hath, that yet

54] And of himself his knowledge is but small: $1653=$ And that himself he knoweth least of all

55] think there are: $1653=$ thinks there is 
58] And striving both they do shut out wise fate: $1653=$ By striving both hinders predestinate

60] that contraries: $1653=$ Contrariety

6I] was: $1653=$ were

64] Who: $1653=$ Which

\section{A Dialogue between an Oak and a Man Cutting him Down}

Copy-text: Poems and Fancies (I664)

I] which largely bend: $1653=$ both large, and long

2] And from the scorching sun you do defend: $1653=$ That keep you from the heat, and scorching sun

3] Which: $1653=$ And

4] And kept you free from thund'ring rains and wet: $1653=$ From thund'ring rains I keep you free, from wet

5] you'd: $\mathrm{r} 653=$ would

I7] And shall thus be requited my: $1653=$ And will you thus requite my love

I8] That you will take: $1653=$ To take away

21] See how: $1653=$ And thus

22] And tried: $1653=$ Invent

24] Chop off my limbs, and leave me nak'd and thin: $1653=$ Hew down my boughs, so chops off every limb

28] this: $1653=$ thus

33] you: $1653=$ they

37] doth fly: 1653 = flieth

38] and of: $1653=$ strong, or

39] do: $1653=$ they

4I] they: $1653=$ do

42] they'll: $1653=$ will

43] Grow: $1653=$ Grows

46] heav'n has saved: $\mathrm{I} 653=$ heaven saved

47] he dies: $1653=$ they die

55] at all times: $1653=$ as they ought

56] men's humours, but their crimes: $\mathrm{I} 653=$ their humours but their fault

58] what: $1653=$ how

59] Though: $1653=$ If

67] you live: $1653=$ thou liv'st

68] seek: $\mathrm{I} 653=$ seek'st 
69] you down, that knowledge you: $1653=$ thee down, 'cause knowledge thou

7I] you: $1653=$ thou

72] you do: $1653=$ thou dost

73] do rise: $1653=$ rise high

74] You: 1653 = Thou

75] And bow their lofty heads, their pride to check: $1653=$ Their lofty heads shalt bow, and make them stoop

76] Shall set your steady foot upon their neck: $1653=$ And on their necks shalt set thy steady foot

77] They; your: $\mathrm{r} 653=$ And; thy

78] your: $1653=$ thy

79] you: $1653=$ thou

84] run in danger, some: $1653=$ dangers run, some new

86] am: $1653=$ were

87] shall I: $\mathrm{I} 653=\mathrm{I}$ should

88] will: $1653=$ would

92] Then: $1653=$ So

93] With sails, and ropes men will: $\mathrm{I} 653=$ Besides with sails, and ropes

94] And I: 1653 = Just like

95] such colds shall take: $1653=$ shall take such colds

96] through holes, and leak: $1653=$ and leak through holes

Ioo] troubles are: $\mathrm{I} 653$ = trouble, is

I02] I'll; I'd: I653 = I; would

I06] you: $1653=$ thou

I07] you: $1653=$ thou

I09] Your: $1653=$ Thy

IIO] shall you: $1653=$ thou shalt

III] i'th': $1653=$ in

II2] there: $1653=$ their

II3] and yet: $1653=$ yet can

I 8 ] With nails and hammers they will often wound: $1653=$ And many times with nails, and hammers strong

II9] And; round: I653 = They; on

I23] Such vain delights I matter not: $\mathrm{I} 653=\mathrm{I}$ care not for these vain delights

I28] men: $1653=\operatorname{man}$

I32] Here you the sun with scorching heat doth burn: $1653=$ For here you stand against the scorching sun

I33] And all your leaves so green to dryness turn: $1653=$ By's fiery beams, your fresh green leaves become

I34] Also: $1653=$ Withered 
I35] And: $1653=$ Thus

I36] I'm happier far, said th'Oak, than you mankind: $\mathrm{I} 653=$ Yet I am happier, said the Oak, than man

I37] For I content in my condition find: $1653=$ With my condition I contented am

I38] Man: $1563=\mathrm{He}$

I45] them: $1653=$ pains

I46] you do not know: I653 = thou understand'st

I49] has: $\mathrm{I} 653=$ hath

I50] and doth to heav'n: $1653=$ doth to the heavens

I5I] For curiosities he doth: $1653=$ A curiosity for to

I52] and: $1653=$ which

I54] afraid: $1653=$ as feared

I56] as a king, his favourite waxing: $\mathrm{I} 653=$ to a king, his favourite makes so

I57] May well suspect, that he his pow'r will get: $1653=$ That at the last, he fears his power he'll get

I58] a man's: $1653=$ man's

I59] That: $\mathrm{I} 653=\mathrm{A}$

I60-6I] For no perfection he at all doth prize / Till he therein the gods doth equalise: $1653=$ And never can be satisfied, until $/ \mathrm{He}$, like a god, doth in perfection dwell.

\section{A Dialogue between a Bountiful Knight and a Castle Ruined in War}

Copy-text: Poems and Fancies (1664)

I] how great is thy change: $1653=$ how thou now art changed

9] Towers upon: $1653=$ And towers on

Iо] Walls, like a girdle, went about: $1653=$ Like to a girdle, walls went round

I2] To view; do: $\mathrm{I} 653$ = viewing; did

I3] Where like a garden is each field and close: I653 = Where every field, like gardens, is enclosed

I4] grows: $1653=$ growed

I6] And hear: $1653=$ Hearing

I7] I'm: $\mathrm{I} 653=\mathrm{am}$

20] held: $1653=$ thought

22] has: $1653=$ hath

25] those passages you see: $\mathbf{I} 653=$ they passages made out

26] Made, and destroyed the walls that circled me: $1653=$ Flung down my walls, that circled me about 
27] left: $\mathrm{I} 653=1 \mathrm{et}$

28] I'm: $\mathrm{I} 653=\mathrm{am}$

33] My windows broke, the winds blow in, and make: $1653=\mathrm{My}$ windows all are broke, the wind blows in

34] That I with cold like shivering agues shake: $1653=$ With cold I shake, with agues shivering

40] I'll: $1653=$ will

4I] have I: $\mathrm{I} 653=\mathrm{I}$ have

42] I'll: $\mathrm{I} 653=\mathrm{Will}$

43] But to restore thy health, and build: $\mathrm{I} 653=$ Thy health recover, and to build

45] then: 1653 = that

46] But all what's: $\mathrm{I} 653=$ For what is

49] This your great: $1653=$ For this your

50] and: $1653=$ of

\section{The Clasp}

Copy-text: Poems and Fancies (1664)

I] Give me a free and noble style, that goes: $1653=$ Give me the free, and noble style

2] In an uncurbèd strain, though wild it shows: $\mathrm{I} 653=$ Which seems uncurbed, though it be wild

3] For though it runs about: $1653=$ Though it runs wild about

8] And not bound up: $1653=$ Not to be bound

\section{The Hunting of the Hare}

\section{Copy-text: Poems and Fancies (I664)}

Like several other poems, 'The Hunting of the Hare' is revised heavily between the first edition of 1653 and that of I664, including the change of the whole poem from present to past tense.

2] Whose body pressed to th'earth, lay close and squat: $1653=$ Pressing his body close to earth lay squat

3] did lie: 1653 = close lies

4] With his grey eyes he glared obliquely: $\mathrm{I} 653=$ Glaring obliquely with his great grey eyes

5] set: $1653=$ sets

6] His tail when turned, his hair blew: $1653=$ If turn his tail his hairs blow 
7] And made him to get cold; but he being wise: $1653=$ Which he too cold will grow, but he is wise

8] Doth keep: $1653=$ And keeps

9] rests he all the day, till th': $\mathrm{I} 653$ = resting all the day, till

Io] up he riseth his relief: $\mathrm{I} 653=$ riseth up, his relief for

II] And walks: $1653=$ Walking

I2] Then coming back in's former posture lies: $1653=$ Then back returns, down in his form he lies.

I4] which came with their dogs: $1653=$ with their dogs which came

15] Whom seeing, he got up, and fast did run: 1653 = Seeing, gets up, and fast begins to run

I7] had: $1653=$ have

I8] traced: $\mathrm{I} 653=$ trace

20] echo: $1653=$ echoes

22] Seeing each shadow thought the dogs were there: $\mathrm{I} 653=$ Thinks every shadow still the dogs they were

23] their cry: $1653=$ the noise

24] did employ: 1653 = new employs

27] been, but straight in's: $1653=$ sat, but straight his

29] Then starting up with fear, he leaped, and such: $1653=$ Starting with fear, up leaps, then doth he run

30] Swift speed he made, the ground he scarce did touch: $1653=$ And with such speed, the ground scarce treads upon

3I] straightways he got: $1653=$ he straight way gets

32] And; sat: $1653=$ Where; sits

33] Where: $1653=$ At

34] Brought him such terror, that his heart did ache: $1653=$ Did bring such terror, made his heart to ache

39] he sat: $1653=$ did sit

43] grey: $1653=$ great

47] he was tired: $1653=$ weary was

53] The hounds so fast came on, and with such cry: $1653=$ Thus they so fast came on, with such loud cries

54] had; could spy: $1653=$ hath; espies

56] that: $1653=$ the

57] was: $1653=$ is

58] was: $1653=$ is

59] did: $1653=$ doth

6o] the grass or track where the scent: $1653=$ what grass, or track the scent on

6I] For witty industry is never: $\mathrm{I} 653=$ Thus quick industry, that is not

62] 'Tis like to witchcraft, and brings: $1653=$ Is like to witchery, brings 
63] But: $1653=$ For

65] that: $1653=$ it

66] the: $1653=$ for th'

69] did: $1653=$ they

$70]$ voices round; $1653=$ voice around

7I] such: $1653=\mathrm{a}$

72] That, had they spoken words, 't had been: $1653=$ If they but words could speak, might sing

73] men did: $1653=$ hunters

74] seemed most valiant, poor Wat to: 1653 = valiant seem, poor Wat for to

76] Swam; leaped: $1653=$ Swim; leap

77] Endangered; they'd ride: $\mathrm{I} 653=$ Endanger; will ride

79] At last: $1653=$ For why

80] That their sharp teeth they: $1653=$ That they their sharp teeth

8I] he fell: $1653=$ did fall

82] Gave: $1653=$ Gives

83] made: $1653=$ make

84] imprisoned had: $\mathrm{I} 653=$ did prisoner take

85] but did: $1653=$ do but

87] men do; $1653=$ man doth

90] Which doth proceed from others': $1653=$ And appetite, that feeds on

92] Kill silly sheep, they say: $\mathbf{I} 653=$ To kill poor sheep, straight say

94] more: $1653=$ them

95] God did make: 1653 = that God made

96] And gave: $1653=$ To give

98] For to destroy those lives that God did: $1653=$ Destroy those lives that God saw good to

I00] which; $1653=$ that

IOI] gentle and mild: $\mathrm{I} 653=$ gentle, mild

I02] of all creatures he's: $1653=$ he of creatures is

I03] Nay, so proud, that he only thinks to live: I653 = And is so proud, thinks only he shall live

Io6] Were: $1653=$ Was

\section{A Description of an Island}

Copy-text: Poems and Fancies (1664)

In the I664 version of this poem, used here, past tense replaces the present tense of the I653 version.

Title] A Description of an Island: $1653=$ Of an Island 
3] not missed: $1653=$ don't miss

4] they kissed: $1653=$ do kiss

5] Each wave did seem by turn to: $1653=$ Where every wave by turn do

6] when as they did flow: $1653=$ as they overflow

7] brought: $1653=$ bring

8] did glister as: $\mathrm{I} 653=$ do glister like

9] did: $1653=$ do

Io] Placing them in her havens with great care: $1653=$ And in her havens places them with care

II] for no pay they'd: $1653=$ They no pay will

I2] But as her guard did: 1653 = Yet as her guard they

I3] circled: $1653=$ circle

I4] without: $\mathrm{I} 653=$ still out

I5] The winds did serve her, and on clouds did: $1653=$ So winds do serve, and on the clouds do

I7] Serving as scouts, they searched: $1653=$ And serve as scouts, do search

18] galloped in the forests: $1653=$ gallop in the forest

19] While she did please the gods, she did live safe: $1653=$ And while she please the gods, in safety lives

20] And they all kinds of pleasures to her gave: $1653=$ They to delight her, all fine pleasures gives

2I] was: $1653=$ is

22] were: $1653=$ are

23] took; did sing: $1653=$ take; do sing

24] did: $1653=$ do

25] thrived; for she their roots well fed: $1653=$ thrive; this isle their roots do feed

26] And tall with pride, their tops did: $1653=$ Grow tall with pride, their tops they

27] Danced; did: 1653 = Dance; do

28] Played; a: 1653 = Play; the

29] did: $1653=$ do

30] hopped, and skipped; were: $1653=$ hop and skip; are

3I] did: $1653=$ do

32] And; strived: $1653=$ Thus; do strive

33] All; looked: $1653=$ And; look

34] were: $1653=$ are

35] Th'isle was their mother: $1653=$ Their mother the island

37] Who dressed and pruned them often with great care: $1653=$ Who takes great care to dress, and prune them oft 
38] And washed their leaves with dew to make them fair: $1653=$ And with clear dew, he washes their leaves soft

39] Which being done, he wiped: $\mathrm{I} 653=$ When he hath done, he wipes

4I] Paint: $\mathrm{I} 653=$ Paints

42] Veiled: $1653=$ Veils

42] dressed, their hairy leaves spread out: $1653=$ dresses, spreads their hairy leaves

44] Wreathed round their crowns his golden beams about: $1653=$ And round their crowns his golden beams he wreaths

45] esteemed: $1653=$ esteems

46] he had loved: $1653=$ we find he loves

47] Daily he did present her with some gift: $1653=$ Presents her daily with some fine new gift

49] came, he put on fair: $1653=$ comes, he puts on clean

50] That lovely she and handsome might appear: $1653=$ And changes oft, that she may lovely seem

5I] from her went: 1653 = goeth from her

52] left; her for: 1653 = leaves; for her

53] Whose name is Cynthia: $1653=$ Cynthia she is

55] left his stars to wait on her: $\mathrm{I} 653=$ leaves his stars to wait, for fear

56] Lest she should grieve too much: $1653=$ His isle too sad should be

57] clothed: $1653=$ clothes

59] brought: 1653 = brings

6o] let; lapped: 1653 = lets; laps

6I] He mantles rich of equal heat o'erspread: $1653=$ With mantles rich of equal heat doth spread

62] covered: $1653=$ covers

63] gave: $1653=$ gives

65] did: $1653=$ doth

66] Like: $1653=\mathrm{As}$

67] fringed: $1653=$ fringes

68] And; hung; 1653 = Where; hang

69] gave he: $\mathrm{I} 653=$ gives her

7I] adorned: $1653=$ adorns

72] riv'lets, prospects round: $1653=$ prospects, and rills that run

73] Hills over-topped the dales, which level were: $1653=$ There hills o'er top the dales, which level be

74] And covered all with cattle, feeding there: $1653=$ Covered with cattle feeding eagerly

75] Grass grew: $1653=$ Where grass grows

76] lay pleasantly: $\mathrm{I} 653=$ in pleasure lie 
79] her love to th'gods willing: $\mathrm{I} 653=$ willing to th'gods her love

8I] And temperate seasons gave: $\mathrm{I} 653=$ Gave temperate seasons

82] Warm: $1653=$ The

\section{The Ruin of this Island}

Copy-text: Poems and Fancies (1664)

Title] this: $1653=$ the

4] and: $1653=$ so

5] and in their stead: $1653=$ her own set up

6] Set up her own, and would be worshippèd: $1653=$ And she alone would have divine worship

I2] That they and mortal men: $1653=$ That mortal men, and they

I3] thought it did show: $1653=$ they thought it showed

I4] the gods did not poor men foreknow: $1653=$ poor man the gods had not foreknowed

I6] did: $1653=$ do

17] did man first: $1653=$ made, or were

20] Wherefore: $1653=$ If so,

24] two: $1653=$ to

25] The one pow'r cannot: $1653=$ Having no power to

28] Know not: $1653=$ Nor know

29] But may't not be the course of God's decree: $1653=$ But may not God's decree on this line run

30] wheresoe'er it be: $1653=$ whensoe'er it come

3I] They from the first a changing power create: $1653=$ So from the first variation creates

32] make destiny and fate: $1653=$ made destiny and fates

33] It is the mind of man: $1653=$ Then 'tis the mind of men

34] The minds of gods are not: $1653=$ And not the minds of gods

37] would: $1653=$ will

38] Revenge on them, who did: $1653=$ Even high revenge, since she

39] like: $1653=$ up

40] Bad vapours from the earth, and then did: $1653=$ The vapour bad from all the earth, then

4I] on: $1653=$ in

42] The venom had, got from the world's great ball: $\mathrm{I} 653=$ The venom was, that's got from the world's ball

43] Then: $1653=$ Which

44] did like oil their spirit all inflame: $1653=$ And like to oil, did all their spirits flame 
47] Thinking which way their lusts they might fulfil: $1653=$ Studying which way might one another rob

48] Committed thefts, rapes, murders at their will: $\mathrm{I} 653=$ In open sight do ravish, boldly stab

49] Parents and children did unnatural: $\mathrm{I} 653=$ To parents children unnat'rally

50] every friend was turned a: $\mathrm{I} 653$ = former friendship now's turned

5I] Nay: $1653=$ For

53] they did: $1653=$ did they

55] did in tumults rise: $\mathrm{I} 653$ = in a tumult rose

56] And 'gainst the heavens utter blasphemies: $1653=$ Blasphemous words against high heaven throws

57] The gods in rage unbound the winds to blow: $1653=$ Gods in a rage unbind the winds and blow

58] a strange nation: 1653 = foreign nations

59] themselves did plant, the natives all: $1653=$ did plant themselves, no Britons live

6o] Were by them killed, for th'gods had sworn their fall: $1653=$ For why the gods their lives, and land them give

66] i'th'grave rest quietly: $1653=$ in graves shall quiet lie

\section{Wherein Poetry Chiefly Consists}

Copy-text: Poems and Fancies (I664)

Title] Wherein Poetry Chiefly Consists: $1653=$ [without title]

Io] but plain, and her skin: I653 = 'tis plain, and skin is

II] that from her thanks are: $\mathrm{I} 653=$ from her a thanks is

I7] the form is, flesh, blood, skin and bone: $1653=$ is the form, flesh, blood, bone, skin

I8] substance they have none: $\mathbf{I} 653=$ have no substance in 20] of: $\mathrm{r} 653=$ to

\section{A Description of a Shepherd's and Shepherdess's Life}

Copy-text: Poems and Fancies (I664)

Title] A Description of a Shepherd's and Shepherdess's Life: $1653=$ A

Description of Shepherds, and Shepherdesses

3] doth: $1653=$ do

4] they being: $1653=$ being 
5] Through the sun's heat their skin doth yellow grow: $1653=$ The sun doth scorch the skin, it yellow grows

6] winds that blow: $1653=$ wind that blows

7] tops of mountains high: $1653=$ mountains top, that's high

8] And: $1653=$ Yet

Io] moss: $\mathrm{I} 653=$ moist

II] are small, but strong each sinew's string: 1653 = though small, strong are their sinews' string

I2] makes: $1653=$ make

I4] He: $1653=$ And

I5] as; is: $1653=$ to; was

I9] He lazy, yawning: $1653=$ And yawning, lazy

20] Or on his back, and hath his: $1653=$ Or straight upon his back, with

2I] his: $\mathrm{I} 653=$ their

22] hobgoblins: $1653=$ hobgoblin

23] his: $1653=$ their

25] Then takes his knife half broke, but ground again: $1653=$ Or takes his knife new ground, that half was broke

26] his sheep-coat up to pin: $1653=$ to pin up his sheep-coat

28] amorous tunes, which pleases his love Joan: $1653=$ tunes that pleaseth Joan his love at home

30] verse and: $1653=$ sonnets

32] follow: $1653=$ driving

33] And dance: $1653=$ Dancing

35] They would their lovers: $1653=$ For they their loves would

38] And: $1653=$ With

40] A fair white hand doth hate a: $\mathrm{I} 653=\mathrm{A}$ white hand sluttish seems in

\section{The Clasp: Of Fairies in the Brain}

Copy-text: Poems and Fancies (I664)

Title] The Clasp: Of Fairies in the Brain: $1653=$ The Clasp. Of Small

Creatures, Such as we Call Fairies

I] that in every: $1653=$ in the

2] Those creatures we call fairies: $1653=$ Little small Fairies

3] frame: $1653=$ make

4] which we fancies name: $1653=$ we for fancy take

6] May by their industry be: $1653=$ By their industry may

Io] they: $1653=$ out 
II] And thus: $1653=$ Thus

I2] May fairies: $1653=$ Fairies

I3] then th'eye's the sea, where by the gale: I653 = the eye's the sea they traffic in

I4] Of passions, on salt tears their ship doth sail: $1653=$ And on salt wat'ry tears their ship doth swim

I5] And when: $1653=$ But if

I7] There: $1653=$ When

I8] And fly up to: $1653=$ Fly up into

I9] great storms: 1653 = storms use

20] Where: $1653=$ Which

22] knocking they may: $\mathrm{I} 653=$ knocking hard they

23] a: $1653=$ the

25] they, like stone: $\mathrm{I} 653=$ like to stone

\section{Upon the Funeral of my Dear Brother, Killed in these Unhappy Wars}

Copy-text: Poems and Fancies (I664)

Title] Upon the Funeral of my Dear Brother, Killed in these Unhappy

Wars: $1653=$ Of a Funeral

I] my funeral mourner be: 1653 = condole my funeral

2] is allied to me: $\mathrm{I} 653=$ doth my life concern

6] But in my fate, though sad, rejoicèd all: $1653=$ But all rejoicèd in my fate, though sad

8] spleen and: $1653=$ and their

9] know: $1653=$ have

Io] But like fierce beasts in savage wildness go: $1653=$ But all in savage wilderness do delight

II] poor: $1653=$ pure

I3] my doleful knell ring out: $\mathrm{I} 653$ = ring out my knell

I4] hearse about: $1653=$ hearse

I5] The birds, as mourners on my tomb shall sit: $1653=$ And birds as mourners sit thereon

I6] like as a covering grow on it: $1653=$ a covering grow upon I7-20] I653 has additional lines:

Rough stones, as scutcheons, shall adorn my tomb,

And glowworm burning tapers stand thereby;

Night sable covering shall me over-spread,

Elegies of mandrakes groans shall write me dead. 
I7] come near me: $1653=$ dig me up

I8] in peace rest quietly: $1653=$ lie quietly in peace

I9] He: $1653=$ For

\section{Lucy Hutchinson}

The copy-text for De rerum natura is British Library, Add. MS I9333. The copy-text for 'To Mr Waller upon his Panegyric to the Lord Protector' is British Library, Add. MS I70I8. The copy-text for the elegies is Nottinghamshire County Archives, Manuscript DD/Hu2. Although the elegies are not in Hutchinson's hand and therefore we do not know whether she intended them to be presented in a particular order, this edition includes the number of the poems as they appear in the manuscript. The copy-text for Order and Disorder, extracts from Cantos I and 3, is Order and Disorder, or, The World Made and Undone being Meditations upon the Creation and the Fall: As it is Recorded in the Beginning of Genesis (London, I679; Wing A 3594; on EEBO). These extracts are collated against the manuscript version of the poem, Beinecke Rare Book and Manuscript Library, MS Osborn fb Ioo. The Beinecke manuscript is the copy-text for the extract from Canto 9, which occurs only in it. 'All sorts of men through various labours press' is extant only in Julius Hutchinson's I808 edition of Hutchinson's Memoirs of the Life of Colonel Hutchinson. The manuscript he transcribed from is lost.

\section{De rerum natura}

Copy-text: British Library, Add. MS I9333, Lucy Hutchinson, 'De rerum natura'

\section{To Mr Waller upon his Panegyric to the Lord Protector}

Copy-text: British Library, Add. MS I70I8, fols 213-17

'To Mr Waller upon his Panegyric to the Lord Protector' exists in a single manuscript and is attributed to Lucy Hutchinson in the hand of 
Henry Hyde, second Earl of Clarendon (' $\mathrm{M}^{\mathrm{rs}}$ Hutchinson's Answer to $M^{\mathrm{r}}$ Waller's Panegirique to the Cromwell'). In his article attributing the poem to Hutchinson, David Norbrook also advises caution about the attribution, pointing out some inconsistencies with her political views expressed elsewhere, though argues strongly overall for her authorship ('Lucy Hutchinson versus Edmund Waller').

63] highness's: $M S=$ Highs

Elegy I. 'Leave off, you pitying friends, leave off'

Copy-text: Nottinghamshire County Archives, Manuscript DD/Hu2 This poem is untitled in the MS.

50] chaste: $\mathrm{MS}=$ cheast

Elegy 2. To the Sun Shining into her Chamber

Copy-text: Nottinghamshire County Archives, Manuscript DD/Hu2 I] day: $\mathrm{MS}=\mathrm{dad}$

Elegy 2(a). 'Ah! Why doth death its latest stroke delay'

Copy-text: Nottinghamshire County Archives, Manuscript DD/Hu2 This poem is untitled in the MS.

\section{Elegy 3. Another on the Sunshine}

Copy-text: Nottinghamshire County Archives, Manuscript DD/Hu2 I9] rapine: $M S$ = rampine

2I] not: $M S=$ no

37] thrust: $M S=$ thurst

\section{Elegy 7. To the Garden at Owthorpe}

Copy-text: Nottinghamshire County Archives, Manuscript DD/Hu2

8] soul: $M S=$ sould

9] just: $M S=$ jus

30] hide: $M S=$ hid 


\section{Elegy Io. The Recovery}

Copy-text: Nottinghamshire County Archives, Manuscript DD/Hu2 Millman and Wright (eds), Early Modern Women's Manuscript Poetry, p. I07: 'the leaves containing this poem are disordered. Lines $45^{-76}$ follow a later poem in the manuscript, "The Consecrated Atoms Sleeping here"'. See also Norbrook, 'Lucy Hutchinson's "Elegies”, p. 506.

II] centre, all: $\mathrm{MS}=$ Centriall

24] enthroned: $M S=$ enthornd

38] cast: $\mathrm{MS}=$ cas

\section{Elegy I2. Musings in my Evening Walks at Owthorpe}

Copy-text: Nottinghamshire County Archives, Manuscript DD/Hu2

I] groans: $\mathrm{MS}=$ groances

7] present: $M S=$ prevent

22] offer: $M S=$ offers

73-74] In the manuscript the final couplet is prefixed by letters that remain unexplained:

A: I: Even then I loathed your flatteries

B: D: And now your sick souls despise

Elegy 20. 'You sons of England whose unquenched flame'

Copy-text: Nottinghamshire County Archives, Manuscript DD/Hu2 This poem is untitled in the MS.

Order and Disorder: The Preface

Copy-text: Order and Disorder (I679)

\section{Order and Disorder: Canto I, lines I-I5O}

Copy-text: Order and Disorder (I679), collated with Beinecke Rare Book and Manuscript Library, MS Osborn fb Ioo

2] admires: $\mathrm{MS}=$ desires

I2] Which, though opposing, he must yet fulfil: $M S$ = Which yet he by opposing doth fulfil 
23] with: $M S=$ in

28] imperfect: $\mathrm{MS}=$ unperfect

29] forms: $M S$ = form

39] mortals': MS = mortal

42] bound: $M S$ = bounds

44] God: $\mathrm{MS}=$ marginal note: The Creator

45] Elohim: $\mathrm{MS}=$ marginal note: Bara Elohim

48] Between lines 48 and 49, MS has two extra lines:

His essence wrapped up in mysterious clouds

While he himself in dazzling glory shrouds.

55] frail: $M S$ = vain

62] mortal: MS = mortals'

79] Unite: $M S=$ Unity

89] Wherein: $\mathrm{MS}=$ In which

92] blessedness: $\mathrm{MS}$ = happiness

I02] After line IO2 the MS has the following instead of lines I03-22:

And all, in all God's works cooperate

Although the action we appropriate

Only unto that person which most clear

And eminently therein doth appear

So we the Father the creator name

Though Son and Spirit joined in the world's frame

And were that Elohim who first designed

The final line in this section has been corrected (by one of several hands in the MS) as follows:

Was the great Elohim who first designed

I40] magazine: $\mathrm{MS}=$ magazines

I4I] Where power, love, justice, and mercy shine: $\mathrm{MS}=$ Where power, love, wisdom, justice, mercy shine

Order and Disorder: Canto 3, lines 9I-I88

Copy-text: Order and Disorder (I679), collated with Beinecke Rare Book and Manuscript Library, MS Osborn fb Ioo

97] doors: $\mathrm{MS}=$ door

99] curtains: $M S=$ curtain

II2] thick-set: $\mathrm{MS}=$ thickest

II3] shows: $\mathrm{MS}=$ looks

122] by: $M S=$ in

I35] MS: marginal note: 'Paradise'

I48] feign: $M S$ = frame 
I60] tall-growing pines and cedars: $M S=$ tall pines and growing cedars I62] scarcely: $\mathrm{MS}=$ not

I82] captived Hebrew's: $M S=$ Hebrew captives

I84] the: $M S=$ their

Order and Disorder: Canto 9, lines I-I22

Copy-text: Beinecke Rare Book and Manuscript Library, MS Osborn fb IO०

'All sorts of men through various labours press'

This poem is extant only in Julius Hutchinson's 1808 edition of Hutchinson's Memoirs of the Life of Colonel Hutchinson. The manuscript he transcribed from is lost.

All references to the Bible are from the King James Version of I6II. 